\title{
Desain Mebel Denmark dalam Konteks Perkembangan Desain Kontemporer Skandinavia
}

\author{
Jamaludin $^{*}$, Imam Buchori ${ }^{* *} \&$ Imam Santosa $^{* *}$ \\ *Fakultas Senirupa dan Desain ITENAS \\ *Fakultas Senirupa dan Desain ITB
}

\begin{abstract}
Denmark's strategic geographical position between Continental Europe and Scandinavian region makes them play a role as a bridge between both regions, including in the development of modern design. The development of Scandinavian furniture design influenced by proto-modern design movement in Europe such as Art and Craft Movement, De Stijl, Vienna School, Deutsche Werkbund, and also Bauhaus. The outer influences were accepted with critical understanding and blended with local character to produce a new design form known as Modern Scandinavia. Historically, the education of modern furniture design in Denmark and other Scandinavian countries pioneered by Kaare Klint (1888-1954) in the Royal Danish Academy of Fine Art, School of Architecture in Copenhagen. It was for the very first time, Klint arranged a systematic and comprehensive study about function, structure and furniture dimension based on British classics chair design. He also studied measurement of furniture based on the necessity of objects, which later known as Ergonomic.

Klint's approach resulted in a functional aspect that lead to organic abstraction form by using natural wood as opposed to Bauhaus form concept that tended to use geometric abstraction form by using chrome-plated metal. Having described its historical roots, the study analyzed the characteristic of Denmark furniture design development that referring to (a) the values of craftsmanship, which is applied into modern design and manufacture process; (b) the commitment to natural material, which is used in furniture design, and (c) social idealism that applied in the society. Danish furniture designers' approach into modern design starts by reductionism that simplifies classical forms into basic-structural forms, and apply organic abstraction as opposed to Bauhaus’s geometric abstractions..
\end{abstract}

Keywords: furniture; design development; Denmark.

\section{Pendahuluan}

Skandinavia adalah istilah geografis untuk menyebut kawasan di Eropa utara yang terdiri dari lima negara yaitu Denmark, Norwegia, Swedia, Finlandia dan Icelandia. Secara historis kelima negara itu merupakan keturunan bangsa Viking yang terkenal kemampuannya dalam melakukan pelayaran ke Eropa Selatan hingga ke Amerika Utara. Lokasi geografis Skandinavia yang berbatasan langsung dengan Kutub Utara memberi karakter khas yang berbeda dengan kawasan lainnya di Eropa.

Received May $6^{\text {th }} 2007$, Revised July 23 $3^{\text {rd }} 2007$, Accepted for publication August $8^{\text {th }} 2007$. 
Letak geografis Denmark yang strategis-antara Eropa Kontinental dan kawasan Skandinavia- memiliki posisi sebagai jembatan antara kedua wilayah tersebut, termasuk di dalam bidang pengembangan desain. Denmark adalah sebuah negara berbentuk kerajaan konstitusional dengan sistem pemerintahan parlementer dengan kepala pemerintahan dikepalai oleh perdana menteri. Nama resmi negara Denmark adalah den Danske Kongelige atau the Kingdom of Denmark. Kepala negara dewasa ini adalah Ratu Margrethe II. Denmark terdiri dari 403 pulau dengan 100 pulau yang dihuni, dengan dua pulau besar yaitu Sjæland (Inggris=Zealand) dan Fyn (Inggris=Funen) serta semenanjung Jutland yang berbatasan langsung dengan Jerman. Wilayah Denmark relatif kecil bila dibanding negara tetangganya. Luasnya hanya $43.094 .16 \mathrm{~km}^{2}$ dengan garis pantai $7.313 .93 \mathrm{~km}$.

Populasi penduduk Denmark termasuk kecil yaitu sekitar 5,5 juta orang. Meskipun demikian, warganya memberi sumbangan besar bagi kemajuan peradaban manusia. Hal ini dibuktikan misalnya oleh H.C. Ørsted (1777-1851) yang menemukan elektromagnetik dan tokoh-tokoh lain yang untuk penemuannya mendapat hadiah Nobel. Mereka adalah Tycho Brahe (15461601) yang menemukan prinsip astronomi fisika modern dan salah seorang perintis eksplorasi antariksa dengan teleskop, Niels Finsen (1860-104) untuk Fisiologi dan Pengobatan, terutama untuk karyanya berupa penggunaan sinar ultraviolet untuk tujuan medis, Johanes Fibiger (1867-1928) untuk penelitiannya mengenai penyakit kanker, Valdemar Poulsen yang mengembangkan 'device' untuk menghasilkan gelombang radio, Niels Bohr (1885-1962) dan Aage Bohr untuk bidang Fisika Quantum, Carl Peter Henrik Dam, penemu vitamin K dan sebagainya. Dalam bidang sastra terdapat Hans Christian Andersen yang karyanya diterjemahkan ke berbagai bahasa di dunia. Dalam bidang filsafat terdapat nama Soren Kierkegaard (1813-1855), filsuf yang membantu membentuk aliran Neo-Eksistensialis dan posisinya sering disejajarkan dengan Nietzsche. Dalam bidang musik terdapat nama Carl Nielsen (1865-1931) komposer musik klasik yang dikenal secara internasional.

\section{Perkembangan Desain Skandinavia Modern}

\subsection{Pengaruh Eksternal}

Sebagai negara yang berbatasan langsung dengan Jerman, Denmark menjadi negara Skandinavia pertama mendapat pengaruh dari apa yang terjadi di Jerman, tanpa kehilangan karakter lokalnya yang khas.

Pada awal era industri, Skandinavia dipengaruhi secara dominan oleh pendekatan Art \& Craf Movement dari Inggris yang dimotori oleh William Morris dan oleh Deutscher Werkbund di Jerman. Belakangan, ketika 
pendekatan 'teknologis' Bauhaus mulai menyebar ke seluruh Eropa, desainer mebel Skandinavia lebih terfokus pada Vienna School suatu 'mazhab desain' yang dikembangkan Wiener Werkstätte di Wina Austria. Vienna School dianggap acuan ideal desain Denmark dan menjadikannya acuan eksternal, terutama terobosan yang dilakukan Michael Thonet dalam desain mebel [1].

Kondisi masyarakat Austria kurang lebih sama dengan kondisi di Skandinavia, yaitu sama-sama memiliki tradisi pertukangan (craftmanship) yang kuat-berakar pada gaya periode Beidermeir-yang terus dikembangkan ke dalam desain pasca PD II dengan bentuk-bentuk sederhana dan dengan kualitas yang tinggi. Dengan latar demikian, desainer Wina menolak aspek revolusioner desain Bauhaus untuk tujuan pelestarian tradisi dan budaya yang telah mapan. Sikap tersebut kemudian juga dilakukan di Skandinavia. Peran langsung desainer Wina terhadap perkembangan desain Skandinavia dilakukan oleh Josef Frank (18851967), desainer Wina yang pindah ke Swedia untuk bekerja pada perusahaan mebel Swedia.

Meskipun demikian, menurut versi [2] pengaruh ideologi Modernisme (Bauhaus) yang paling kuat justru terdapat di Skandinavia. Dalam kondisi sosial politik yang relatif tenang di Denmark, Swedia dan Finlandia, prinsip-prinsip Modernisme memberi pengaruh yang penting dalam pengembangan desain di kawasan itu. Meskipun demikian, Denmark dan negara Skandinavia lainnya menyikapi pengaruh itu dengan pandangan kritis dengan cara mengkaji ulang prinsip itu dan memahaminya lebih dalam untuk kemudian menggabungkannya dengan karakter dan tradisi Skandinavia yang kuat.

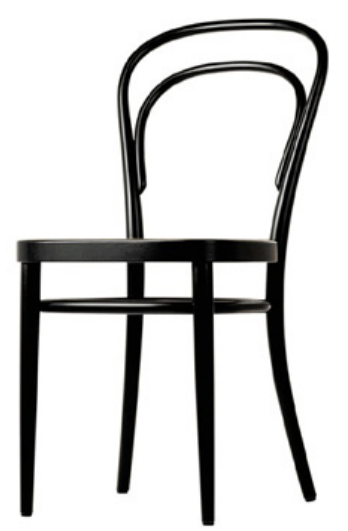

Gambar 1 Kursi no. 14 karya Michael Thonet, 1885 (Sumber: Thonet de). 


\section{$2.2 \quad$ Pengaruh Internal}

Bentuk pengaruh internal adalah adanya karakteristik lokal Skandinavia yang berperan penting dalam pengembangan desain mebel modern. [3] menganalisis pengembangan desain di Skandinavia didasarkan atas penggabungan tiga hal pokok, yaitu:

1. Tradisi craftmanship

Tradisi craftmanship dan nilai-nilai yang dikandungnya memainkan peran yang sangat penting dalam kehidupan sosial di kawasan Skandinavia. Kuatnya tradisi ini membuat pemisahan antara seni dekorasi (decorative art) dan desain industri terlihat kabur dan baru dapat dipisahkan belakangan [4]. Masyarakat dan desainer Skandinavia melihat bahwa decorative art dan desain industri saling memberi inspirasi secara langsung. Apa yang dimulai sebagai eksperimen dalam art decorative sering direalisasikan sebagai produk yang 'terdesain'. Tradisi craftmanship berpengaruh besar terhadap teknik dan eskpresi artistik desain Skandinavia.

Tradisi dan karakter craftmanship yang kuat di Skandinavia dikembangkan secara intensif dalam industri mebel sehingga kemudian menjadi kekuatan dan ciri khas. [1] melihat apa yang dilakukan di Skandinavia ini sebagai sistem "craft-influenced industry" bukan "craft-based industry”. Hal yang sama diutarakan Penny Sparke:

"While Germany sells design in the name of science, Italy in the name of art, Scandinavia in the name of craft and the USA in the name of business, all these national image of design were necessary strategies in the highly competitive markets of the immediate post war years. The role of the designer was to help develop a marketing strategy which would give his products a spcecial place in the market." [2]

Meskipun pernyataan Sparke di atas dalam konteks persaingan pasar tetapi sesungguhnya hal di atas mencakup cara pandang atau sikap desainer Skandinavia terhadap karyanya yang merupakan kelanjutan dari tradisi dan sebagai cermin dari sikap hidup masyarakat secara umum.

\section{Modernisme}

Prinsip-prinsip Modernisme yang datang dari Bauhaus Jerman diterima secara kritis termasuk di dalamnya metode baru dalam produksi dengan metoda industrialisasi. Aspek-aspek Modernisme diadaptasi melalui penyesuaian dengan karakter masyarakat Skandinavia.

Fungsionalisme yang telah menjadi semangat kaum Modernisme adalah faham yang menghendaki suatu objek desain dibuat dalam bentuk 
sederhana, jujur dalam menunjukkan material dan konstruksi, sesuai bagi peruntukannya, tidak memakai ornamen dan dibuat dengan standardisasi Hal ini sesuai dengan definisi Fungsionalisme Kathryn B. Hiesinger, "As the idea that beauty in useful object is defined by their utility and honesty to material and structure" [1].

3. Idealisme Sosial

Idealisme sosial yang dimaksud adalah arah perkembangan masyrakat Skandinavia sendiri dalam mengembangkan dirinya menuju suatu masyarakat modern dengan prinsip-prinsip yang sesuai dengan pandangan hidup secara umum di Skandinavia. Wujud dari idealisme sosial ini berlangsung dalam bentuk reformasi sosial pasca PD II yang dimotori oleh ideologi Sosialis Demokrat dan kemudian Welfare State.

Woodham [2], berpendapat bahwa desain Skandinavia berkembang mengacu pada sikap umum dalam pengembangan nilai-nilai estetik yaitu a) nilai-nilai craftmanship, b) penghargaan yang tinggi terhadap alam dan c) penghargaan terhadap imajinasi desainer. Tiga hal pokok inilah yang secara politis dan budaya membedakan desain Skandinavia dengan desain dari negara Eropa lainnya.

Material alam mendapat apresiasi yang tinggi di masyarakat dan desainer Skandinavia, karena dipandang dapat menginterpretasikan nilai-nilai manusiawi yang terdapat pada karakter budaya Skandinavia. Komitmen inilah yang kemudian dikenal dengan sebuatan yang khas merujuk pada desain Skandinavia Modern. Penggunaan material alam, dipicu oleh antara lain pernyataan perintis desain Modern Finlandia, Alvar Aalto, "the human body should came into contact only with organic material" [3]. Stainless-steel yang dipakai sebagai media mebel modern Bauhaus, pada awal perkembangan mebel modern di Skandinavia sangat dihindari karena mereka lebih menghargai material alami yaitu kayu. Setiap prototop mebel dibuat seluruhnya dari kayu. Baik kayu solid maupun kayu lapis bending. Penggunaan material metal baru belakangan dipakai, kebanyakan untuk bagian yang tidak berhubungan langsung dengan tubuh manusia.

Alvar Aalto di Finlandia, Arne Jacobsen di Denmark dan Bruno Mathsson di Swedia mengandalkan penggunaan kayu (material alam) dalam upaya melakukan pendekatan terhadap desain modern. Aalto memberikan sumbangan yang signifikan terhadap desain modern melalui ekperimennya dengan membuat kursi dari bahan kayu lapis bentwood yaitu kursi 'Paimio' yang pertama kali dibuat pada tahun 1931-30. 


\subsection{Denmark}

Pengembangan desain mebel Denmark telah dirintis secara sistematis sejak 1770 yaitu ketika Kuntsakademiet Arkitekskole didirikan. Kampus itu bertanggungjawab mengembangkan keahlian menggambar dan membuat desain mebel yang baik. Salah seorang pengajarnya adalah NH Jardin, arsitek dari Perancis yang berjasa menyebarkan pengetahuan mengenai arsitektur dan desain mebel Neoklasik. Untuk mewadahi kegiatan di lapangan, pada 1777 didirikan det Kongelige Møbelmagasin (Pusat Permebelan Kerajaan) dipimpin oleh GE Rosenberg. Lembaga ini mengatur masalah penyediaan material, mode, gambar untuk dipakai di bengkel kerja dan usaha lainnya untuk meningkatkan kualitas produk serta menjualnya.

\section{$2.4 \quad$ Swedia}

Perintisan desain mebel modern Swedia dilakukan oleh Carl Malmsten (18881972) dengan pengaruh dari Art \& Craf Movement Inggris. Malmsten membuka College of Handicraft and Popular Art dan membentuk jaringan kerjasama antara sekolah yang menyediakan suasana kreatif dengan pihak industri. Dengan kata lain, Malmsten menggabungkan dunia pertukangan dengan aspek fungsi yang dilahirkan Modernisme tetapi dengan tetap mengadakan pendekatan terhadap nilai-nilai tradisional, mengikuti apa yang dilakukan Kaare Klint di Denmark.

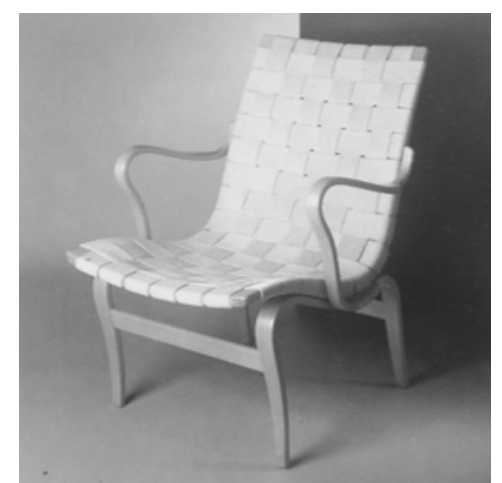

Gambar 2 Kursi karya Bruno Mathsson (Sumber: Charlotte).

Perkembangan desain modern Swedia selanjutnya dikembangkan Gunnar Asplund melalui karyanya berupa gedung pameran Werkbund Exhibition di Stockholm yang menggunakan prinsip desain modern dengan material baru seperti kaca dan baja. Karya yang kemudian mempengaruhi generasi berikutnya seperti Bruno Mathsson (1907-1988). Gerakan estetik baru itu dikenal dengan nama Swedish Modern. 


\section{$2.5 \quad$ Finlandia}

Finlandia adalah satu-satunya negara di Skandinavia yang berbentuk Republik setelah sebelumnya menjadi wilayah jajahan Swedia dan Russia. Kondisi sebagai bekas negara jajahan ini membuat Finlandia mempunyai semangat nasionalisme yang tinggi. Salah satu bentuknya adalah upaya penggalian budaya lokal Finlandia yang dikembangkan ke dalam segala aspek kehidupan, termasuk di dalamnya dalam masalah seni dekorasi (decorative art) dan seni terapan (applied art). Perintisan desain modern dengan berakar pada tradisi dilakukan oleh Louis Sparre (1886-1964) dengan cara mencari desain tradisional untuk diadopsi ke dalam desan modern.

Pada 1896, tiga arsitek muda Finlandia yaitu Herman Gesellius, Armas Eliel Lindgren dan Eliel Saarinen membentuk biro desain dengan tujuan mengembangkan desain modern. Generasi selanjutnya adalah Alvar Aalto (1898-1976) yang kemudian menjadi arsitek modern Finlandia terbesar. Pada 1928 Aalto memenangkan sayembara gedung sanatorium di Paimio. Dengan konsep 'total design' yang masa itu sedang tumbuh, Aalto juga membuat desain kursi dan perabotan lainnya untuk sanatorium tersebut.

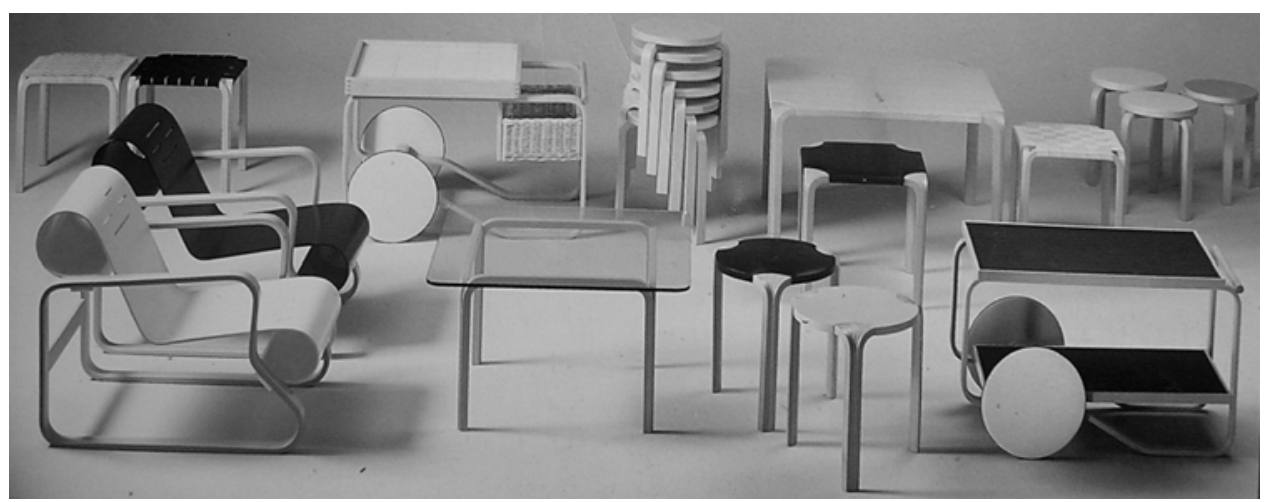

Gambar 3 Rangkaian mebel karya Alvar Aalto seorang arsitek Finlandia.

\subsection{Norwegia}

Industri mebel modern Norwegia menggunakan bahan yang diperoleh dari kekayaan alam khas Norwegia yaitu bermacam kayu pinus dengan kualitas tinggi dan mengadopsi teknologi pembuatan papan ski. Generasi perintis desain mebel Norwegia adalah Rastad \& Relling, Fredrik A Kaiser, Ingmar Relling, Bendt Winge, Torbjorn Afdal, Sigurd Ressel, Tormond Alnaes dan Sven Ivan Dysthe. 
Norwegia melahirkan terobosan revolusioner dalam konsep duduk yang sama sekali berbeda dari konsep yang pernah ada. Konsep ini dikembangkan Peter Opsvik dalam masalah kenyamanan dan ergonomi dengan sudut pandang baru. Konsep duduk Opsvik meletakkan berat badan pada dudukan dan sandaran kaki bagian depan, bukan sandaran punggung. Karyanya dikenal dengan nama 'Balans' [4].
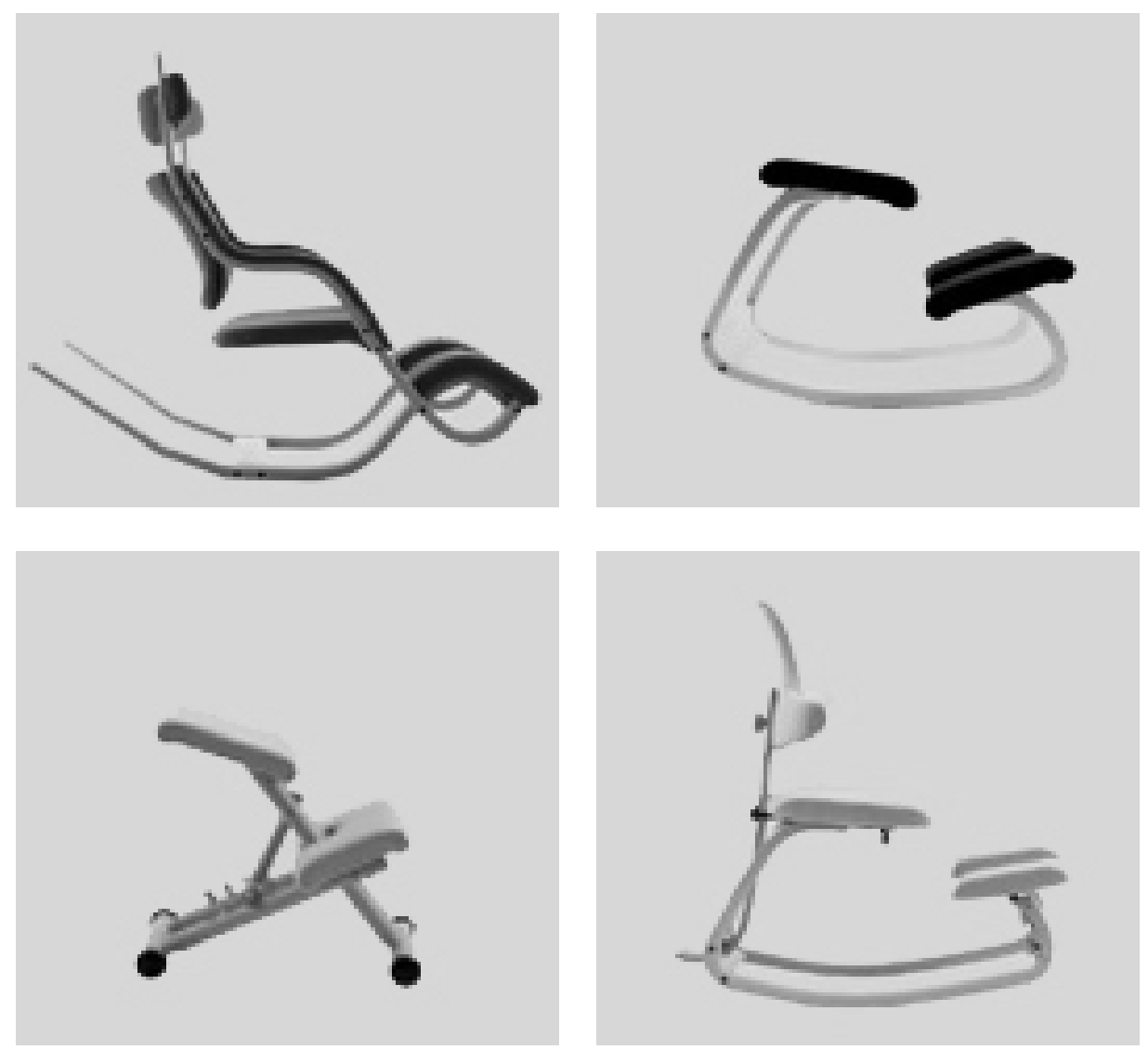

Gambar 4 Kursi Balans dengan berbagai variasi, karya Peter Opsvik Norwegia.

\section{Pengaruh}

\subsection{Desain Skandinavia di Amerika}

Pengaruh desain Skandinavia di Amerika terjadi dalam dua jalur. Pertama dengan didirikannya Cranbrook Academy of Fine Art di Michigan pada 1932, dengan direktur pertamanya seorang arsitek dari Finlandia yang pindah ke 
Amerika yaitu Eliel Saarinen. Sekolah itu menjadi tempat berkembangnya 'desain ogranik' khas Skandinavia di Amerika dan mulai menunjukkan pengaruh melalui beberapa lulusan akademi itu seperti Eero Saarinen, Charles dan Ray Eames, Florence Knoll, Harry Bertoai muncul menjadi pembaharu desain Amerika menuju desain modern yang bersebelahan dengan desain Modernisme yang dibawa Mies van der Rohe, Walter Gropius dan Marcel Breuer-yang lebih berkonsentrasi pada penyempurnaan teknik konstruksi dan material. Cranbrook Academy memberi makna baru bagi sebuah karya desain dengan kualitas seni patung yang secara radikal merubah pandangan para desainer dan konsumen mengenai tampilan bentuk. Karya desain monumental Eero Saarinen adalah bandara udara TWA di JFK Airport yang memperlihatkan karakter Skandinavia -bentuk abstrak ogranik- sangat kuat dalam bangunan tersebut.

Pengaruh kedua melalui ekpor produk mebel dari Skandinavia ke Amerika yang diperkenalkan pada New York World Fair pada 1939. Sejak itu, desain Skandinavia modern mulai dikenal di seluruh Amerika dan dunia. Tahun 1940an, desain di Amerika dikenal dengan nama dekade Skandinavia, suatu bentuk pengakuan Amerika terhadap desain dari Skandinavia yang secara luas dikenal memiliki karakter praktis dan mudah dalam perawatan, sederhanamengingatkan pada gagasan Art \& Craft Movement, indah, homey dengan material kayu pucat khas Skandinavia [5].
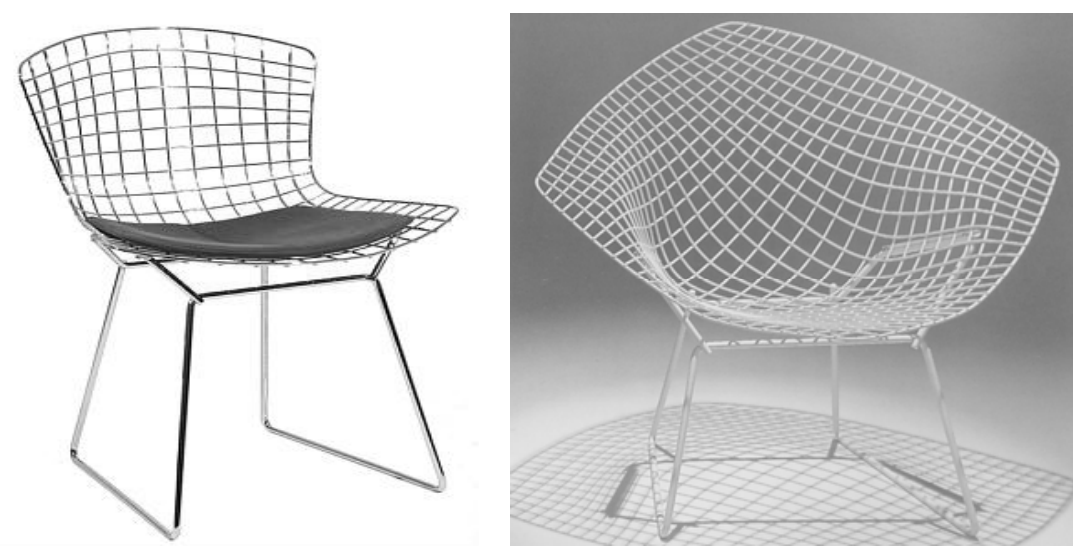

Gambar 5 Kursi karya Harry Bertoia (Sumber: Charlott). 

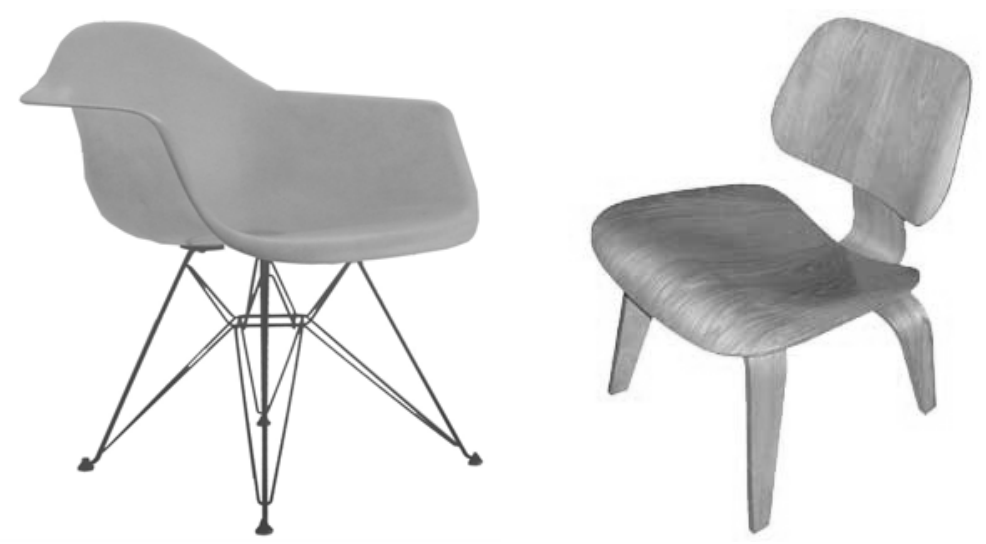

Gambar 6 Kursi karya Charles Eames (Sumber: Charlotte).

\section{$4 \quad$ Perkembangan Desain Mebel Modern Denmark}

\subsection{Latar Belakang Sosial Budaya}

Meskipun Denmark adalah negara berbentuk kerajaan seperti halnya Swedia dan Norwegia, masyarakatnya hidup dalam alam demokratis dan dengan pandangan hidup tanpa pretensi. Winter yang panjang dan lebih dingin dari kawasan Eropa lainnya, membuat orang Denmark dan Skandinavia umumnya lebih banyak tinggal di dalam ruangan. Perspektif hidup bangsa Denmark dikenal dengan istilah "Hygge" yaitu senantiasa berusaha menciptakan kondisi agar lebih nyaman, menyenangkan dan rapi. Konsep hidup ini juga berlaku dalam hubungan sosial yang selalu diupayakan dalam bentuk harmonis. Dengan begitu, masyarakat Denmark akan selalu berusaha memperbaiki kondisi yang tidak nyaman di luar lingkungannya untuk menciptakan kondisi yang hangat dan nyaman di dalam lingkungannya. 'Hygge' mempengaruhi berbagai aspek kehidupan masyarakat Denmark termasuk cara membuat desain rumah dan perabotannya.

\subsection{Gambaran Umum Desain Denmark}

Di abad ke 20, para desainer Debmark berperan penting dalam pengembangan mebel modern dunia. Beberapa karya desainer/arsitek Denmark menjadi ikon baru desain kontemporer dunia. Sepewrti kampus St. Catherine di Oxford Inggris karya Arne Jacobsen, Sidney Opera House karya Jørn Utzøn dan Grande Arche de la Defense karya Johan-Otto Sprickelson di Paris. 


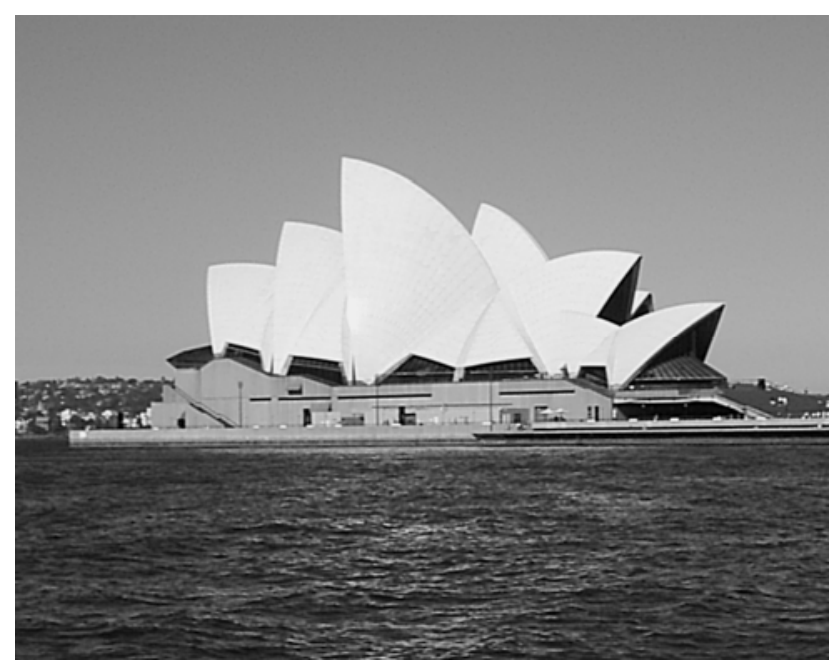

Gambar 7 Sidney Opera House, karya Jörn Utzön, arsitek dari Denmark (Foto: Andi M).

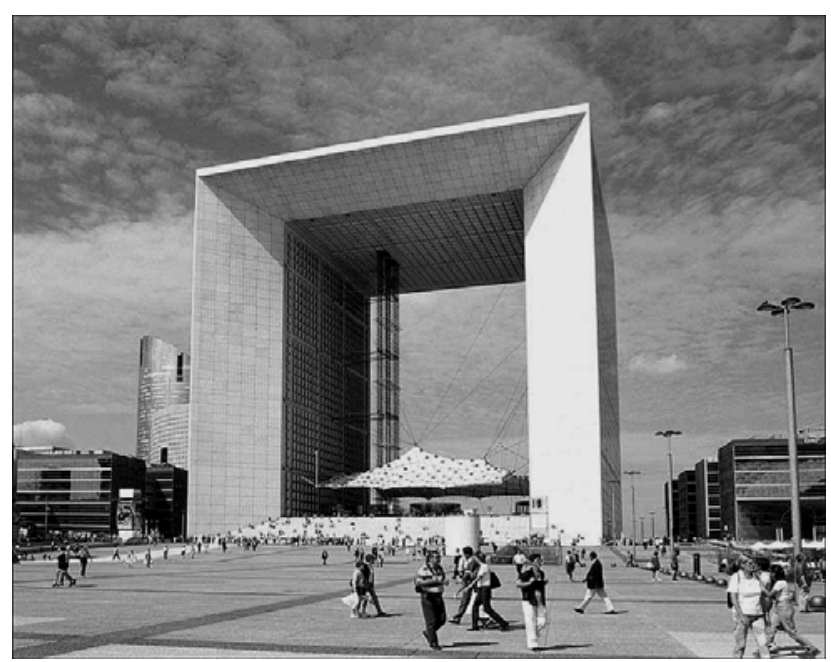

Gambar 8 Grande Arche de la Defense karya Johan-Otto von Spreckelsen.

Menurut Hugh Aldersey-William [6], di seluruh negara Eropa, Denmark memiliki identitas desain paling jelas. Karakter desain produk Denmark tertentu tidak bisa disatukan dengan Swedia dalam konteks 'desain Skandinavia'. Contoh untuk ini adalah desain peralatan elektronik Bang \& Olufsen yang sangat khas Denmark dan mainan 'Lego'. Desain Denmark hanya dapat digabung dalam konteks desain Skandinavia terutama dalam pendekatan bentuk organik seperti terdapat dalam bidang desain mebel. Desain nasional Denmark mengekspresikan “Jante’s law” yaitu versi Denmark untuk peribahasa Jepang 
yang mengatakan bahwa "paku yang menonjol harus dipukul ke dalam barisannya.” Dengan kata lain setiap objek harus terlihat rapi dan teratur.

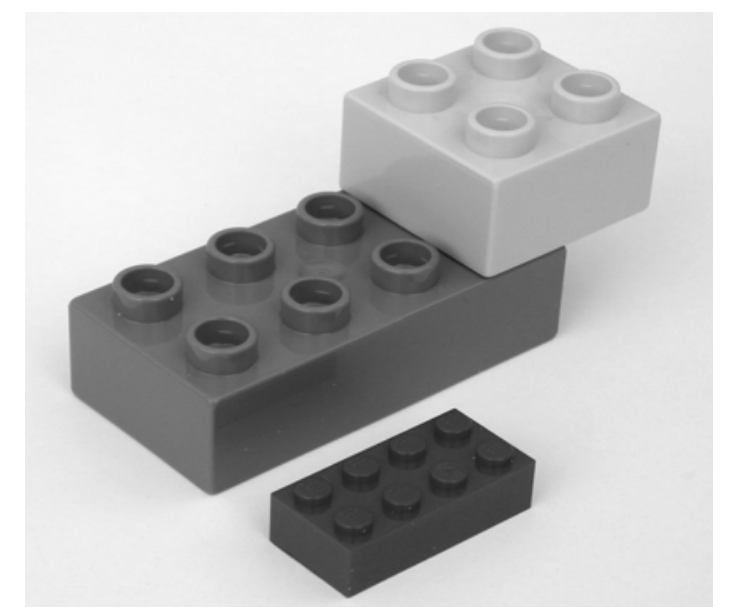

Gambar 9 Permainan 'Lego brick'.

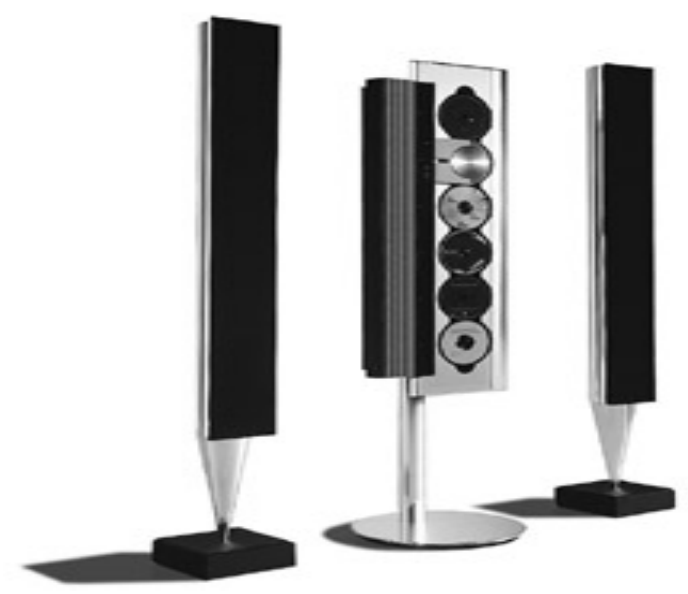

Gambar 10 Produk Bang \& Olufsen.

Secara umum, konsep bentuk desain Denmark terdiri dari dua model. Untuk objek desain yang tidak berhubungan langsung dengan manusia, bentuk yang dikembangkan mirip dengan prinsip estetik yang dikembangkan oleh Vladimir Nabokov, yaitu 'empat persegi panjang rendah' yang diterapkan dalam bentuk umum bangunan. Manifesto konsep ini terlihat jelas pada mainan paling terkenal di dunia buatan Denmark yaitu 'Lego'. Bentuk kedua, adalah bentuk yang dipakai dalam objek desain yang berhubungan langsung dengan tubuh manusia, seperti kursi yang menggunakan bentuk 'abstrak organik', yaitu 
bentuk yang menggunakan referensi bentuk dari alam. Sementara Bauhaus menggunakan prinsip bentuk 'abstrak geometrik', yaitu bentuk dasar dalam desain seperti lingkaran, bujur sangkar dan segi tiga [7].

Prinsip pokok desain Denmark terlihat pada metoda kerja, sebagaimana diungkapkan Hans J Wegner:

“....hal terbaik dari desain Denmark bukanlah gaya atau kecenderungan (trend) yang bersifat fesyen tapi metode kerja untuk menyelesiakan masalah-masalah fungsional yang dikerjakan dengan gaya (style). Objek yang dibuat harus sealami dan seasli mungkin, yang dengan itu semua akan menjadikannya indah. Desain adalah masalah pemahaman terhadap ekonomi yang menyadari bentuk-bentuk alam: konstruksi minimal yang menerima semua elemen beban adalah citra dari kemampuan yang dihasilkan dari fungsi dan bentuk secara keseluruhan [8].

\section{$5 \quad$ Aspek-Aspek Internal yang Berpengaruh pada Perkembangan Desain Mebel Denmark}

\subsection{Pendidikan dan Metode Pengajaran Desain Mebel}

Desain mebel Denmark dibangun di atas tradisi yang spontan dan kuat. Hal yang paling penting mengenai tradisi ini adalah kepedulian terhadap masyarakat terutama kebutuhan akan bentuk dan aspek estetik. Metode pengajaran desain mebel di sekolah desain Denmark menggunakan metode tradisional yang dirintis oleh Kaare Klint. Tradisi ini adalah gabungan dari penghargaan yang tinggi terhadap potensi individu dan pemahaman yang tinggi terhadap lingkungan masyarakat.

Pengajaran desain di Denmark dibangun di atas dua landasan, satu 'perspektif historis' yaitu landasan pengembangan desain berdasarkan tradisi yang telah dirintis oleh pendahulu yang secara terus-menerus diuji dan dikembangkan, dan 'perspektif pendidikan' yaitu pencarian unsur-unsur kebaruan dalam proses pewarisan nilai-nilai yang dimiliki bangsa Denmark sendiri. Hanya bangsa Denmark yang tahu masa lalu dapat merubah dan memperbaiki masa sekarang serta masa depan serta mereka yang berani menentang masa lalu yaitu kaum pelopor dan pengusaha. Pendidikan desain mebel di Denmark menggunakan metoda pengajaran yang mendorong kemampuan untuk menganalisis masalah sehingga mahasiswa dapat dengan kritis menemukan pemecahan yang inovatif. Sistem pendidikan sirkular, bukan linear yang dipakai mampu menghilangkan hambatan bagi kerjasama interdisiplin dan mengembangkan solusi alternatif yang dibutuhkan masyarakat masa depan. 
Pendidikan desain mebel yang dirintis Kaare Klint berkembang dengan dibukanya rumkusnt $ø g$ møbler afdeling (jurusan desain interior dan mebel) dalam lingkungan Arkitekskole (School of Architecture) dan yang berdiri sendiri. Sampai sekarang terdapat enam jurusan desain interior dan mebel di enam kampus, yaitu:

1. den Danske Kunstakademiet Arkitekskole (Sekolah Arsitektur, Akademi Senirupa Kerajaan Denmark) dibuka pada 1754 di Kopenhagen

2. Arhus Arkitekskole, Aarhus

3. Danish Design School, Kopenhagen

4. Frederiksberg Technical School, Frederiksberg

5. School of Art and Craft, Udense

6. Designskolen, Kolding

\subsection{Konsep Ergonomi dan Antropometri Kaare Klint}

Desain Denmark berkembang ke arah desain modern dirintis dengan berbagai upaya. Salah satu melalui pendidikan desain mebel yang dirintis oleh Kaare Klint (1888-1954) dan menjadi guru besar di Kunstakademiet Arkitekskole. Kaare Klint tidak melihat desain masa lalu sebagai artifak yang harus disingkirkan tetapi dianalisis untuk memperoleh prinsip-prinsip teoritis dan ketepatan fisiologis serta aspek fungsinya. Pemikirannya yang terkenal: "do not reveal a carving for newness, but are a restatement of classical solutions combining comfort and dignified simplicity" [7]. Dengan cara itu, pendekatan Klint terhadap desain modern berbeda dengan Marcel Breuer pada masa Bauhaus di Jerman yang bersifat revolusioner. Kaare Klint melihat mebel sebagai sebuah perabotan untuk hidup sehari-hari, bukan sebagai seni patung [9]. Salah satu karya Klint adalah kursi untuk museum seni rupa di Faborg, Funen, 1914. Cara yang dilakukan Klint adalah reduksionisme, yaitu proses pemurnian (purify) desain klasik ke dalam bentuk standar yang hanya menghadirkan struktur tanpa hiasan ornamen seperti halnya pada desain klasik.

Sementara terhadap faham Fungsionalisme, Kaare Klint menilainya melalui pernyataan: "the individual item gets its value from its technical source and by serving its purpose to the utmost." [10]. Pernyataan yang kemudian ia kembangkan dalam berbagai karyanya secara konsekuen sehingga kemudian, secara umum, desain Denmark memperkenalkan sesuatu yang baru yaitu 1) perhatian yang lebih mendalam terhadap interaksi antara pemakai dan perabotan, 2) pemahaman yang lebih organik terhadap bentuk yang dihasilkan dari penelitian, dan 3) eksperimen yang komprehensif terhadap faktor pemakai dan teknologi proses seperti kayu lapis. 

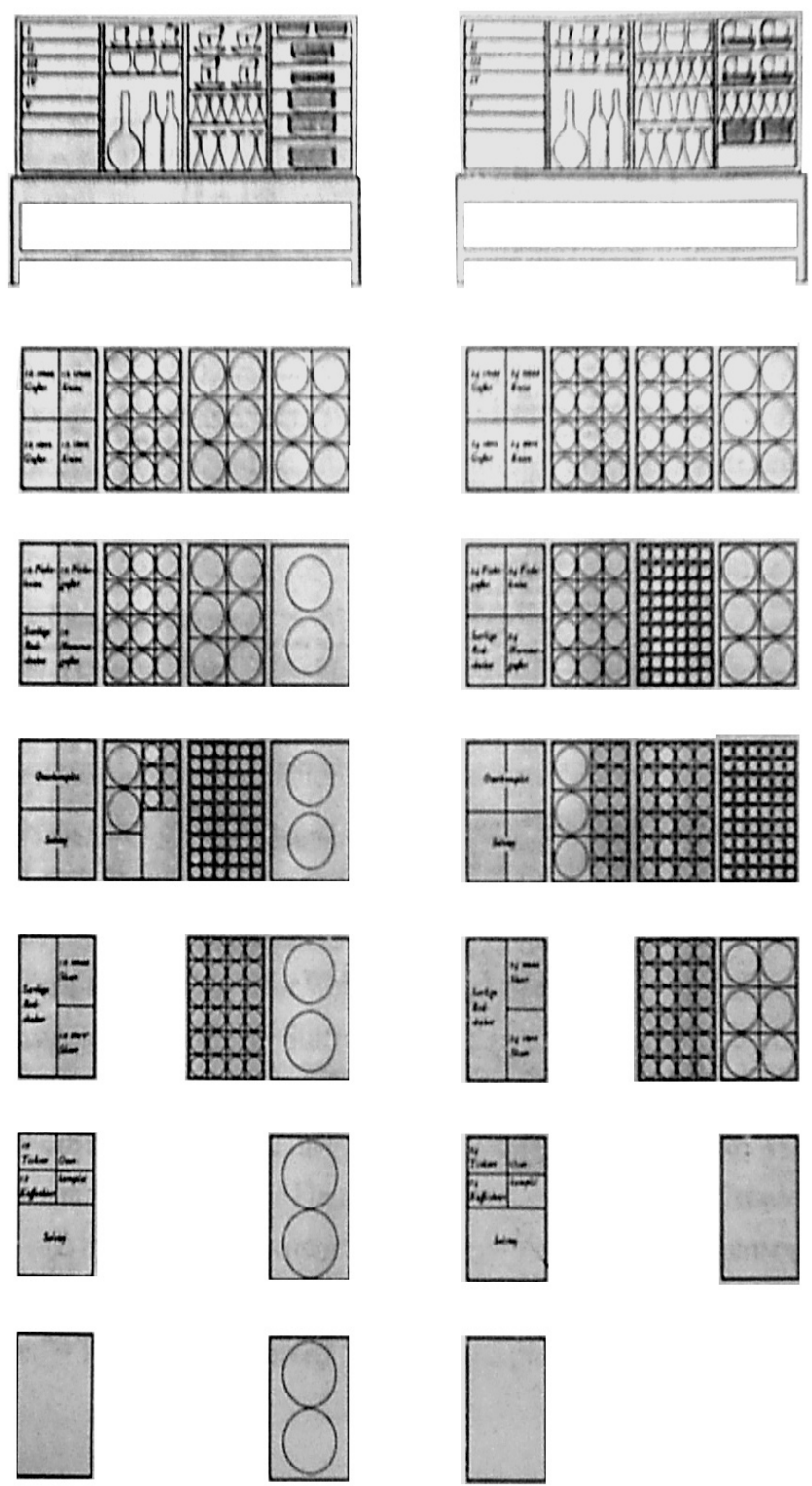

Gambar 11 Salah satu hasil studi Kaare Klint dengan contoh kasus lemari pecah belah (cupboard). Rak lemari masing-masing disesuaikan dengan ukuran piring, botol, tatakan, gelas masing-masing (Sumber: Kaare Klint).

Kaare Klint mengadakan penelitian yang intensif mengenai fungsi dasar suatu mebel seperti peruntukan, ukuran yang paling tepat, proporsi antara manusia 
dengan mebel yang mampu memberikan kenyamanan maksimal bagi pemakai dan teknik konstruksi yang menciptakan kekuatan struktur. Penelitian yang kemudian berkembang menjadi ergonomi atau ilmu yang mempelajari hubungan manusia dan kerja. Cara yang dilakukan Kaare Klint adalah dengan terlebih dahulu membuat semacam tempat percobaan bagi perabotan yang akan disimpan di lemari atau rak tersebut. Untuk membuat lemari piring dan gelas, terlebih dahulu dilakukan percobaan penyimpan piring dalam berbagai posisi yang memungkinkan. Dari penelitian itu didapat ukuran-ukuran standar yang merujuk kepada ukuran berbagai jenis piring, gelas, tatakan dan botol anggur.

\subsection{Lembaga Pengawasan Kualitas Mebel}

Lembaga yang berperan dalam menjaga kualitas di Denmark adalah Lembaga Pengawasan Kualitas Mebel dibawah koordinasi Denmark Technological Institute (DTI). Lembaga ini adalah organisasi independen yang beranggotakan para produsen mebel terkemuka Denmark, sementara DTI sendiri adalah lembaga pemerintah yang salah satu tugasnya adalah untuk merumuskan standar dan pengujian terhadap seluruh produk yang dihasilkan industri Denmark termasuk di dalamnya produk mebel.

Laboratorium pengujian dibangun di kompleks institut di Taastrup, dekat Kopenhagen untuk mengembangkan peralatan uji, dan penerapannya serta pengembangan bentuk konstruksi baru. Standar kualitas dalam mebel, dicapai melalui penelitian intensif untuk meningkatkan kualitas mebel Denmark dalam semua aspek, terutama yang berhubungan langsung dengan masalah teknik, seperti material, kekuatan konstruksi dan sebagainya. Sebelum suatu produk dipasarkan, pihak produsen mengirimkan contoh produk ke DTI dan diuji sesuai fungsi produk masing-masing. Mebel yang memenuhi kriteria atau persyarataan yang ditentukan diberi label lulus uji dan dan dapat dipakai sebagai jaminan kualitas.

Jenis pengujian yang dilakukan antara lain masalah keamanan pengguna termasuk kestabilan, resiko gesekan dan terjadinya bagian yang patah dan untuk jenis mebel tertentu termasuk ukuran yang mungkin akan berpengaruh terhadap segi keamanan mebel tersebut; kekuatan (strength) dan daya tahan (durability) termasuk kekuatan menerima beban (termasuk beban di luar perkiraan), pengaruh beban tersebut terhadap konstruksi dan daya tahan terhadap muatan normal. Pengujian dilakukan secara berulang atau terusmenerus, baik dari segi material maupun konstruksi. Daya tahan permukaan juga diuji untuk mengukur ketahanan terhadap cairan, garukan/goresan, panas dan pukulan. 


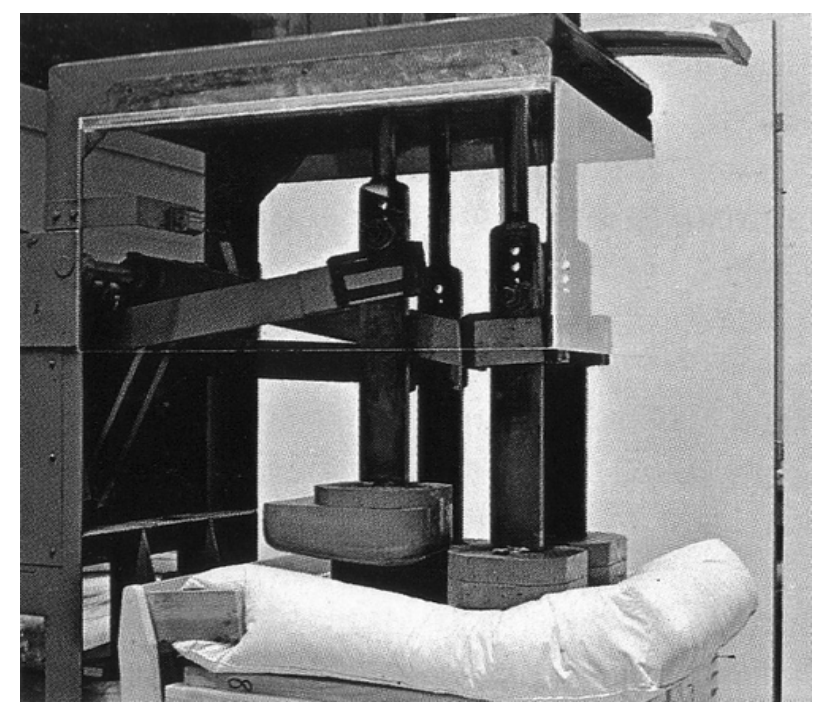

Gambar 12 Alat Uji beban untuk dudukan (Sumber: DTI).

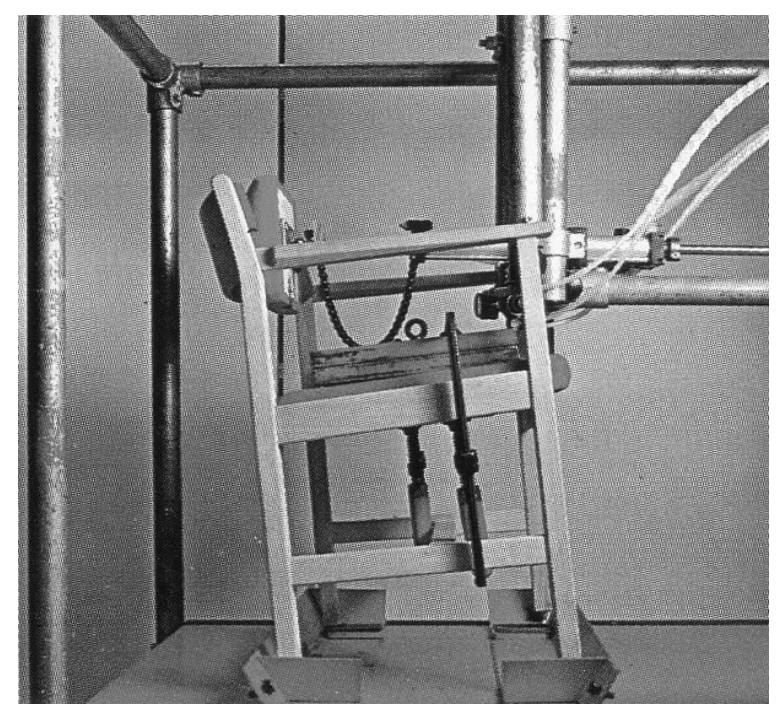

Gambar 13 Alat Uji beban terhadap material dan konstuksi (Sumber: DTI). 


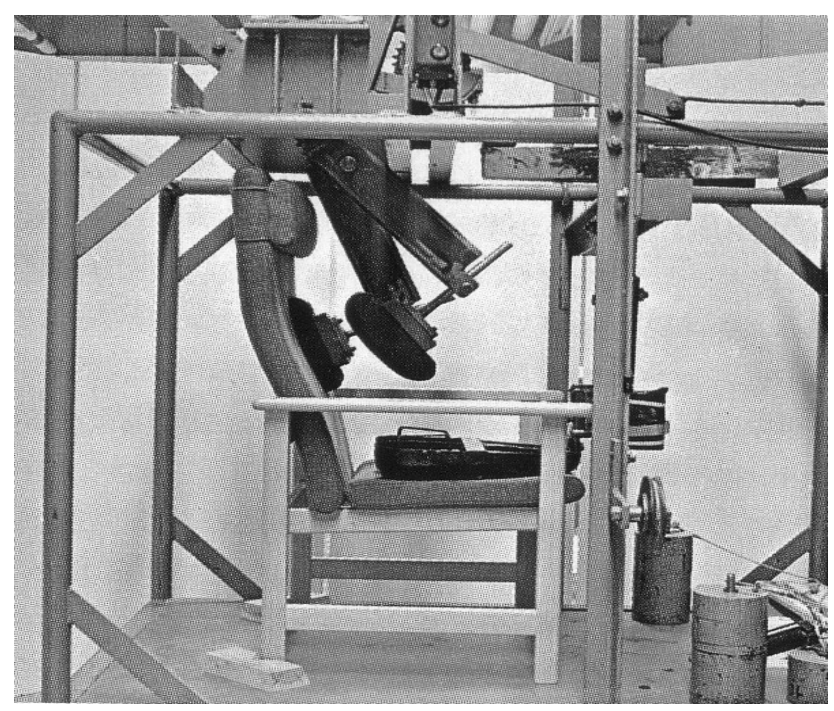

Gambar 14 Alat uji konstruksi dan beban. Uji ketahanan pemakaian beban sandaran dan dudukan (Sumber: DTI).

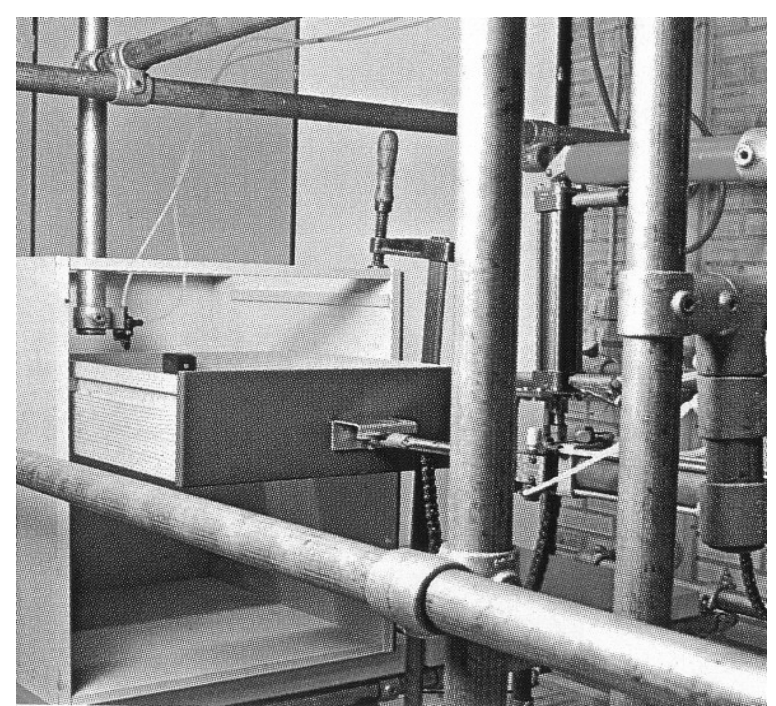

Gambar 15 Pengujian kualitas konstruksi laci/drawer (Sumber: DTI).

\subsection{Pusat Desain Denmark}

Denmark memiliki lembaga pengembangan desain yang dianggap berhasil di Eropa. Lembaga itu adalah Pusat Desain Denmark (Danish Design Center, $D D C$ ) yang didirikan pada 1977. Meskipun bersifat independen, lembaga ini mendapat bantuan teknik dari Kementrian Perindustrian dan Kementrian 
Pendidikan dan Penelitan Denmark dalam upaya mengembangkan kebijakan desain di Denmark. Tujuan didirikannya Pusat Desain Denmark antara lain:

1. Mempromosikan dsain yang baik (good design) kepada industri dan masyarakat Denmark

2. Memperkenalkan desain dan citra Denmark kepada dunia internasional

3. Mendorong pengembangan teori dan praktek dalam desain.

Kegiatan yang dilakukan DDC antara lain:

1. Pemberian jasa informasi mengenai desain

2. Konsultasi manajemen desain

3. Pelatihan dan promosi

4. Penerbitan buku-buku desain karya desainer Denmark

5. Menyelenggarakan pameran, sayembara desain dan pemberian penghargaan (award) bagi desain terbaik dalam periode tertentu.

6. Penelitian desain

Kepengurusan organisasi DDC ditentukan oleh Dewan Desain Denmark (Danish Design Council) yang terdiri dari anggota yang memiliki kualifikasi tinggi dalam bidang desain.

\subsection{Industri Mebel}

Data sampai 1999, industri mebel Denmark tercatat sekitar 500 perusahaan dengan tenaga kerja 22.000 orang. Perusahaan-perusahaan tersebut umumnya berukuran menengah dalam komposisi yang rasional dan memiliki tingkat fleksibilitas tinggi sehingga mampu menyesuaikan diri terhadap berbagai sistem produksi. Setiap tenaga kerja di industri mebel diberi kemampuan tambahan keahlian pertukangan sekaligus penguasaan teknologi modern. Kombinasi keahlian ini menciptakan sikap profesional yang ditujukan untuk menghasilkan produk yang berkualitas tinggi. Jumlah hasil produksi mebel Denmark lebih banyak dibanding negara di Eropa lainnya dan lebih dari 75\% produksi tersebut diekspor.

Produksi mebel Denmark terdiri dari tiga peruntukan segmen pasar:

1. Mebel untuk keperluan rumah tangga (domestik) yang merupakan mayoritas produk yang dihasilkan industri mebel Denmark, termasuk mebel untuk anak-anak, ruang makan, ruang duduk, kamar tidur, dapur dan lainlain. Material utama mebel kategori ini adalah kayu lapis dan solid yang dikemas dalam bentuk kotak dengan sistem sambungan knock-down untuk kemudahan pengiriman (shipping).

2. Mebel perkantoran dan desain khusus untuk perkantoran (contract furniture) yang dipesan oleh arsitek suatu proyek, pemilik gedung dan 
pengusaha untuk memenuhi keperluan ruang kantor, lembaga dan ruang publik.

3. Mebel karya desainer terkenal yang membuat Denmark menjadi salah satu negara terkemuka dalam desain mebel secara internasional sejak awal 1950an. Desain mebel klasik karya desainer terkemuka dan karya inovatif dari desainer generasi baru bersama-sama mempertahankan dan terus memperbaharui posisi Denmark dalam desain mebel dunia. Salah satu perusahaan jenis ini adalah Frizt Hansen yang antara lain memproduksi mebel karya arsitek terkenal Arne Jacobsen yaitu kursi makan Seri 7, the Swan dan the Egg.

Untuk memperkuat pengembangan dan pemasaran, industri mebel Denmark mendirikan Asosiasi Industri Mebel Denmark merupakan organisasi gabungan produsen dan eksportir mebel.

\subsection{Pameran Tetap dan Pameran Tahunan}

Salah satu bentuk pengembangan desain adalah dengan memperkenalkan desain kepada masyarakat luas. Hal ini telah lama disadari oleh desainer dan produsen mebel Denmark. Upaya memperkenalkan karya desainer kepada publik umumnya dalam bentuk pameran dan dipajang pada showroom.

Beberapa bentuk pameran yang ada di Denmark dan diselenggarakan secara rutin adalah: den Permanente berupa pameran tetap, Copenhagen Cabinet Makers' Guild (terhenti sejak 1966), Scandinavia Furniture Expo, Sammenslutningen Snedkernes Esterårsudstilling (SE) atau The Furniture Makers' Autumn Exhibition dan sebagainya. Pameran-pameran ini selain diikuti oleh para produsen mebel juga diikuti kelompok desainer mebel Denmark yang memamerkan karya terakhir yang umumnya bersifat eksperimental.

\section{Perkembangan Desain Mebel Denmark}

Perkembangan secara kronologis desain mebel Denmark relatif tidak memiliki ciri khusus kecuali pada masa perintisan. Kesamaan pemahaman di kalangan desainer mebel Denmark membuat karya yang dibuat pada 1980-an mempunyai karakter yang relatif sama dengan yang dibuat pada 1950-an. Lebih-lebih dengan penggunaan material yang sama seperti kayu lapis bending. Contoh untuk ini misalnya kursi 'seri 7' karya Arne Jacobsen yang dibuat pada 1950-an tampak mempunya semangat yang sama dengan Trinidad karya Nanna Ditzel yang dibuat pada 1980-an. Desain kursi 'seri 7' sendiri tampak tidak ketinggalan zaman. 


\subsection{Era Perintisan (1914-1952)}

Sebagaimana diuraikan di atas, perintisan desain mebel ke arah modern dimulai secara akademik oleh Kaare Klint di Kunstakademiet Arkitekskole Kopenhagen pada 1924. Kaare Klint mengajarkan prinsip-prinsip desain yang kemudian berhasil menjadi pemicu lahirnya desain mebel modern di Denmark dan di negara Skandinavia lainnya. Karya Klint sendiri antara lain kursi Faborg yang dibuat pada 1914 untuk museum seni rupa di kota Faborg pulau Fyn dan masih diproduksi hingga sekarang oleh Rud Rasmussen di Kopenhagen. Tahun pembuatan kursi ini penulis pakai sebagai titik tolak Era Perintisan.

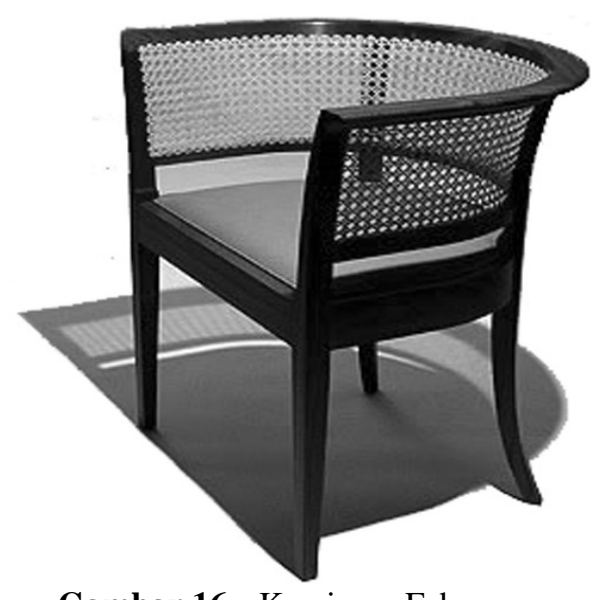

Gambar 16 Kursi Faborg, karya Kaare Klint, 1914 (Sumber: Rudrasmussen. dk).

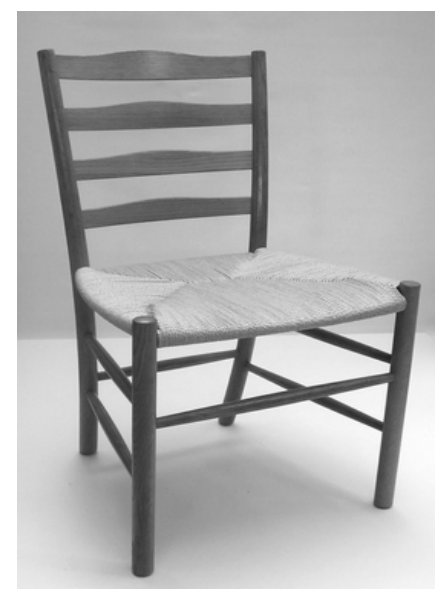

Gambar 17 Kursi gereja, karya Kaare Klint (Sumber: Stoleplet.dk).

Para mahasiswa Kaare Klint kemudian muncul menjadi desainer mebel modern generasi pertama antara lain Borge Mogensen, Hans J Wegner, Ole Wanscher, Mogen Koch, Gjerlov Kundsen, dan Finn Juhl. Periode ini ditandai dengan aplikasi metode Klint terhadap desain mebel klasik Inggris yang dilakukan generasi generasi pertama desainer mebel Denmark terhadap desain mebel klasik dari berbagai sumber. Tiga desainer mebel utama pada periode ini adalah Hans J. Wegner, Borge Mogensen dan Finn Juhl. Pada 1940-an ketiganya menyertakan karya mereka dalam pameran Copenhagen Cabinet Makers Guild. Karya mereka menandai babak baru dalam desain mebel Denmark bersamaan dengan perkembangan desain mebel di kawasan Skandinavia lainnya. Kehadiran karya mereka itu kemudian memberi tanda gerakan desain yang disebut 'Denmark Modern' untuk menandai perkembangan desain mebel Denmark dalam lingkup 'Skandinavia Modern'. 
Pada era ini pula desain mebel Denmark mulai dikenal secara internasional melalui berbagai pameran di kota-kota penting Amerika Serikat yang kemudian memicu ekspor mebel dalam skala besar. Karakteristik desain mebel Denmark yang sederhana, dengan bahan kayu pejal memberi kesan hangat hingga diterima masyarakat Amerika.

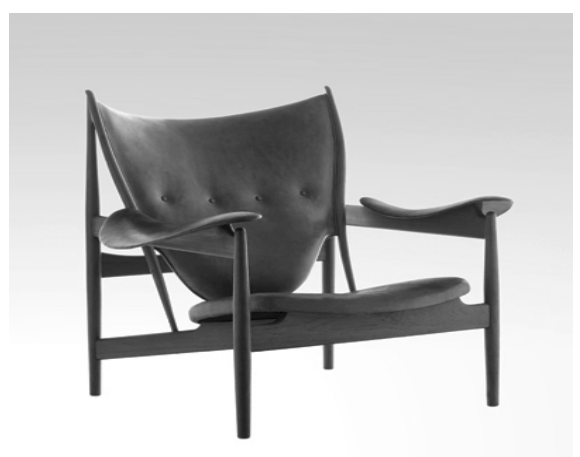

Gambar 18 Kursi Kapten, Karya Finn Juhl, 1949 (Sumber: Niels Vodder, Denmark).

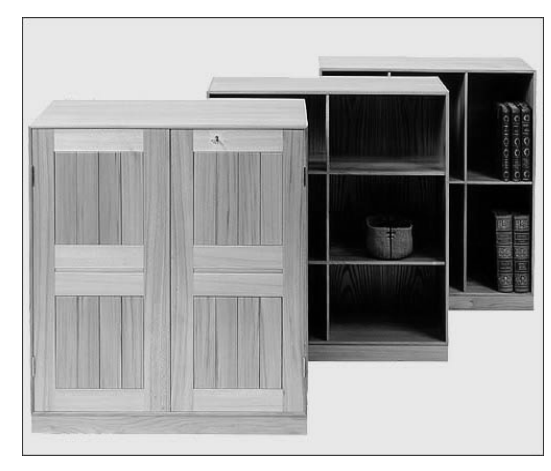

Gambar 20 Kabinet karya Mogen Koch, 1933 (Sumber: Rud Rasmussen, Denmark).

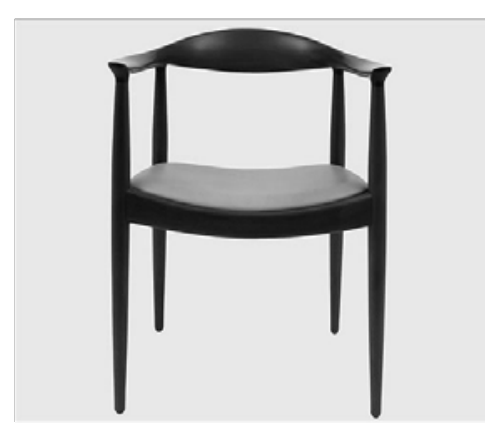

Gambar 19 Kursi Bulat, Karya Hans J. Wegner, 1949 (Sumber: Johannes Hansen, Denmark).

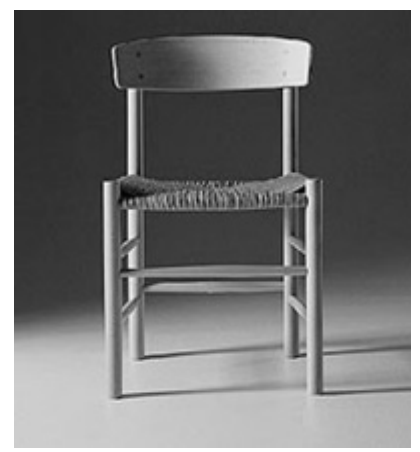

Gambar 21 Kursi Makan, Karya Borge Mogensen, 1947 (Sumber: Co-op, Denmark).

\subsection{Era Perkembangan (1952-1980)}

Tahun 1952 merupakan titik tolak Era Pertengahan berdasarkan karya Arne Jacobsen, Myren (the Ant chair) yang dibuat pada tahun itu. Periode ini ditandai oleh adanya pengaruh dari Bauhaus berupa konsep Modernisme yang diadopsi dengan berbagai penyesuaian yang dapat diterima masyarakat Denmark. Periode ini relatif memiliki jarak dengan periode perintisan karena memuat 
nuansa desain modern yang kuat, terutama dalam pemakaian teknologi kayu lapis bending yang dirintis Alvar Aalto di Finlandia. Dekade 1950-an hingga 1970-an ini merupakan tahap perkembangan desain mebel modern menuju kemapanan. Desain mebel pada periode ini antara lain adalah masterpiece desain mebel modern karya Arne Jacobsen (1902-1971), the Ant, seri 7, the Swan dan the Egg yang kemudian menjadi desain modern klasik, sejajar dengan Barcelona chair karya Mies van de Rohe dari Bauhaus Jerman.

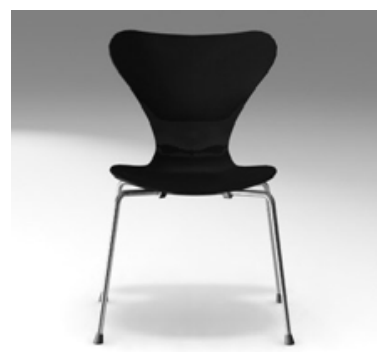

Gambar 22 Kursi seri 7, karya Arne Jacobsen, 1955 (Sumber: Frizt Hansen, Denmark).
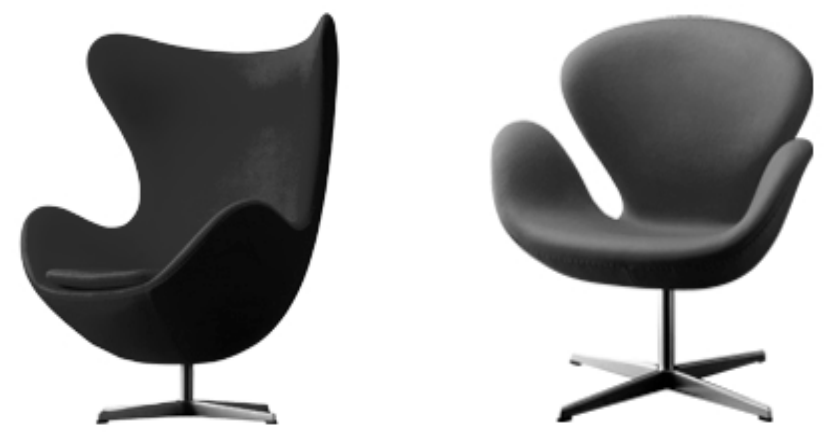

Gambar 23 Kursi The Egg dan The Swan, karya Arne Jacobsen, 1958 (Sumber: Frizt Hansen, Denmark).

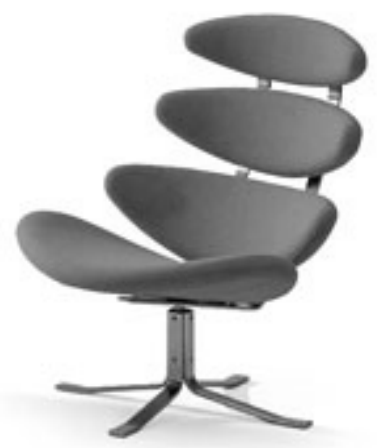

Gambar 24 Corona, karya Poul Volther, 1961 (Sumber: Fredecia Möbler, Denmark). 


\subsection{Era Masa Kini (1970-sekarang)}

Salah satu ciri Era mutakhir ditandai oleh karya Nanna Ditzel, 'Trinidad Chair' yang dibuat pada 1984. Pengolahan kayu lapis bending dalam bentuk baru yaitu dengan membuatnya transparan dengan cara menghilangkan sebagian sehingga mengurangi bidang masif. Pengolahan kayu lapis bending dilanjutkan dengan eksperimen yang lebih kreatif sehingga meskipun dari periode berbeda, masingmasing desain tersebut memiliki benang merah yang memberinya identitas yang sama sebagai desain mebel Denmark dan desain Skandinavia secara umum. Karakteristik yang terus berkembang antara lain penggunaan material kayu lapis bending dengan struktur dari bahan metal yang menggantikan material kayu.

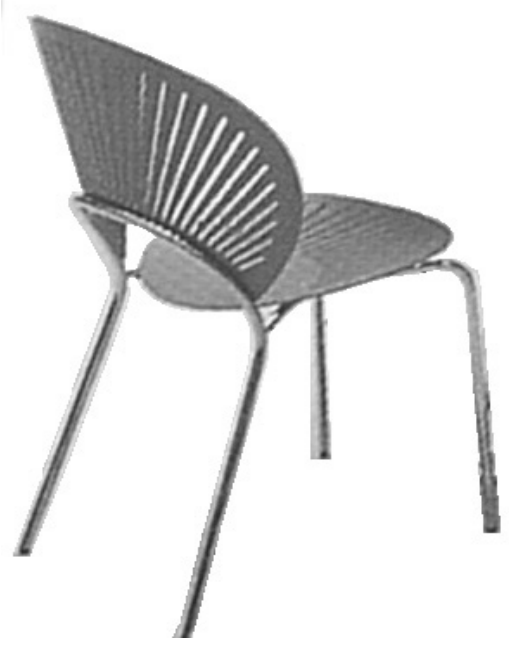

Gambar 25 Kursi Trinidad, Nanna Ditzel, 1984 (Sumber: Fredericia Mobler, Denmark).

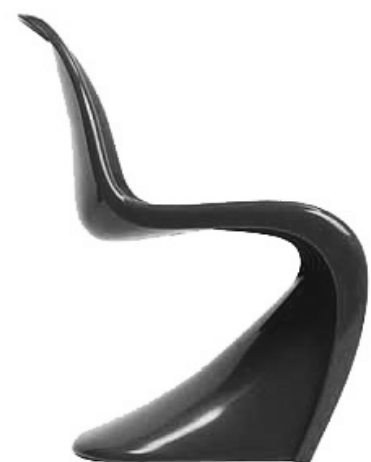

Gambar 26 Kursi stacking karya Verner Panton, 1956, dengan bahan plastik. Kursi pertama di dunia dengan bentuk monocoque. Produksi Vitra (Sumber: Panton.com).

Desain mebel Denmark masa kini juga didominasi oleh material kayu, baik kayu pejal maupun kayu lapis. Di Denmark, material utama yang dipakai untuk merealisasikan gagasan desain adalah kayu. Seluruh desain orisinal Denmark dibuat dengan kayu baik kayu pejal maupun kayu lapis bending yang diolah berdasarkan tradisi craftmanship. Teknologi kayu lapis memungkinkan pengembangan desain mebel berkembang dengan lebih variatif. Perintisan yang dilakukan Alvar Aalto diteruskan di Denmark oleh Arne Jacobsen dan oleh desainer lainnya. 


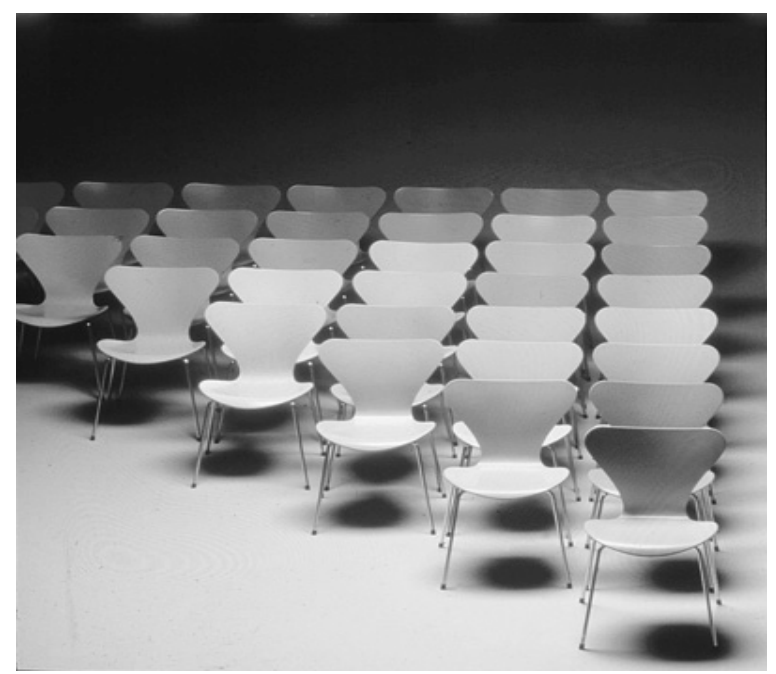

Gambar 27 Kursi seri 7 karya Arne Jacobsen yang diberi warna oleh Verner Panton setelah Jacobsen meninggal (Sumber: Frizt Hansen, Denmark).

\section{$7 \quad$ Simpulan}

Desainer mebel Denmark mengembangkan desain lama melalui inovasi baru dengan mempertahankan nuansa tradisi craftmaship yang kuat. Tradisi ini berkembang ke dalam desain modern Denmark dalam bentuk sikap dan pendekatan desainer dan pihak industri terhadap proses, pemahaman pentingnya detil dan kualitas suatu karya desain. Dengan kata lain, Modernisme di Denmark mengambil nilai-nilai yang terdapat dalam tradisi craftsmanship, terutama yang berhubungan dengan kualitas, yaitu implementasi nilai yang terdapat dalam tradisi craftmanship, bukan dalam hal penggunaan teknologi atau material.

Berkembangnya konsep Reduksionisme yang berarti mengurangi hal-hal yang bisa dihilangkan ke dalam bentuk yang lebih sederhana dan bentuk murni dari suatu desain. Hal yang dilakukan Kaare Klint pada awal masa perintisan desain modern Denmark. Kemudian konsep Reduksionisme Wegner dimulai dengan "membuat garis luar (outline) dari desain kursi lama dan membuatnya muncul dalam konstruksi yang murni” (Dale Mackenzie Brown, dalam House Beautiful, Januari 1997). Wegner mereduksi bentuk desain lama ke dalam rangka -empat kaki, dudukan dan kombinasi sandaran belakang dan sandaran tangan. Di Denmark, apa yang dilakukan Wegner merupakan revolusi, mengingat pada saat itu, rumah-rumah di Denmark dipenuhi oleh mebel 'prestisius' dari peniruan gaya desain zaman tertentu seperti desain mebel Renaisans yang 
berukuran besar, mengisi interior apartemen kecil yang rata-rata dihuni empat orang.

Selain dari mebel Cina, Wegner juga mengambil inspirasi dari mebel klasik Inggris. Di tangan Wegner kursi Windsor Inggris direduksi ke dalam bentuk baru menjadi 'The Peacock Chair' pada 1947. Wegner mentransformasikannya ke dalam bentuk yang lebih besar dan lebih nyaman.

Selain itu, berkembang pula bentuk abstraksi organik, yaitu konsep bentuk desain khas Skandinavia yang berangkat dari penghargaan yang tinggi terhadap bentuk-bentuk alam. Suatu bentuk yang terdiri dari garis yang tidak terputus, lebih kurang seperti kerang (shell) atau bentuk 'biomorphic' yang diambil dari bentuk objek yang hidup [1]. Studi mengenai bentuk ini dirintis oleh Kaare Klint yang kemudian dikembangkan generasi berikutnya menuju bentuk yang sempurna hingga memiliki identitas atau perbedaan yang jelas dengan konsep bentuk ala Bauhaus ataupun de Stijl.

Bentuk ini disebut Rasionalisme organik yang berangkat dari dunia alami sedangkan simetri dan rasionalisme bentuk segi empat abstraksi geometri yang dikembangkan di lembaga Bauhaus berasal dari konsep proporsi dan geometri formal [7]. Desainer generasi pertama Denmark yang mengembangkan mebel dengan pendekatan ini antara lain Finn Juhl yang intensif melalukan eksplorasi bentuk organik.

\section{Daftar Pustaka}

[1] Dormer, Peter. 1993. Design Since 1945, Thames \& Hudson, London, h.29, 55, 120.

[2] Woodham, Jonathan. 1997. Twentieth-Century Design, Oxford, New York, h177.

[3] Mang, Karl. 1978. History of Furniture Design, Harry N. Abrams, New York, h.17, 142.

[4] Peter Butenschon. 1996. Design from Skandinavia No. 19.

[5] Tate, Allen \& Smith, C. Ray. 1988. Interior Design in the $20^{\text {th }}$ Century, Harper \& Row Publisher, New York, h. 392.

[6] Journal New Statesman, Juni 1999.

[7] Fiell, Charlotte \& Fiell, Peter. 1992. Modern Chairs, Benedikt Taschen Verlag GmBH, Koln.

[8] Bensen, Jens. 1994. Hans J. Wegner, Danish Design Center, Kopenhagen, h. 46.

[9] Sparke, Penny. 1998. A Century of Design, Design Pioneers of the $20^{\text {th }}$ Century, Michel Beazley, London, h.64.

[10] Møller, Henrik Sten. 1975. Danish Design, Rhodos Kopenhagen, h. 27. 